Kom, 2016, vol. V (2) : 23-38

UDC: 141.4 Мула Садра Ширази

28-1 Мула Садра Ширази

DOI: $10.5937 / \mathrm{kom} 1602023 \mathrm{~N}$

Original scientific paper

\title{
Religious Language in the Transcendent Philosophy of Mulla Sadra
}

\author{
Mohammad Ali Niyazi \\ Faculty of Philosophy, Al-Mustafa International University, \\ Qom, I. R. Iran
}

\begin{abstract}
Language is the most important communicative element of mankind with other beings that with at least lingual sign the highest level and account of meaning communication occurs. Thus, after the creation blessing, the Almighty mentioned the language as the greatest gift (Quran 55: 41). Also, the Islamic tradition as the guide of humans in the evolution path should have a language that would in the best way be able to play its role in this path and illuminate the divine message for them (Quran 14:4). The two languages have an inseparable link and it is due to this reason that during the human history religion has caused the evolution of language and in each religion a specific language emerged (Hebrew and Jewish, Greek and Christianity, Arabic and Islam, Sanskrit and Hinduism and etc.). Most intellectuals who have dealt with the debate about the language of religion, first investigate the verbal propositions whose subject is God and imply one of the divine attributes or acts. It seems in this context that initially the factors which caused the formation of religious language should be considered.
\end{abstract}

Keywords: Religious Language, Mulla Sadra Shirazi, Religious Propositions, Being Symbolic, Cognitive, Non-Cognitive

\section{Philosophy and Formation of Religious Language}

The semantic problem of divine attributes resulted from the commonness of the joint attributes between the human and God on the one hand, discrepancy within the holy Book and contradiction of its contents with intellect; on the other hand, it led to the discussion of religious language. The

Corresponding author: niyazi1358@yahoo.com 
conflict of science and religion and its resolution through the language of religion and emergence of philosophical schools such as logical positivism and language analytical philosophy have also been very effective in the formation of the philosophy of religious language that added to the necessity of bringing up this discussion and resulted an ambiguity in being meaningful and informative of the religious propositions. In the discussion of the language of the religion, religious propositions can be divided into three groups:

- Propositions existing in religious texts or revealed propositions. A question posed here is:

What language does God speak when he speaks to us?

- Propositions by which we talk about God's names and attributes (see: Barbour 1995: 151).

- Propositions which relate to our conversations with God:

The question which can be posed here is in what language we communicate with God and talk to him. But, Mulla Sadra appeared in an arena where until his time, ideas such as metaphor, transcendence (purification), and combined theory had reached its summit among the intellectuals. Since he was on the peak of this rational evolution, he had been perfectly versed in all the proposed theories; therefore, his scientific command and inherent penchant and intelligence which were joint with intuition and divine providence, led him to choose the best way and method in truth telling of the Quran language which is the allusiveness of the language of the Quran. However, regardless of the discussion on the difference between the language of religion and religious language, in this context, the language of religion implies the revelation language and revelatory propositions; a language in which God's message was expressed; in other words, generally speaking, in the discussion on the language of religion, two issues of meaningfulness and knowledge granting religious propositions are aimed at in the present study. This issue will be specifically discussed in the principles and philosophical thoughts of Mulla Sadra Shirazi, the founder of the Transcendent Wisdom.

\section{Mulla Sadra's Philosophical Principles and Basics}

Obviously, a precise understanding of every thinker's viewpoint depends on an understanding of his intellectual foundations; therefore, if we want to acquire each scholar's view in a particular domain, first we must consider his 
intellectual foundations in order to understand his viewpoint. In the present paper aiming to investigate Sadra's thought regarding the language of religion, to achieve Sadra's standpoint in this area, it is necessary to examine the principles and basics of this Transcendent philosophy; since this discussion was never considered in the present form during Sadra's time, thus, first, we will investigate Sadra's philosophical principles and basics relating to this discussion, and then, according to these basics, we will attempt to acquire Sadra's view in the discussed area of this research.

\section{The Principle of Existentialism}

Existentialism is considered as one of the important basics in Sadra's philosophical system and is highly significant.

\section{Introduction and History}

The issue of the unity of reality may have a very long background in the history of thought. But, the issue of unity of being was originally posed by Muslims and specifically so by Ibn Arabi (1433); however, some people believe that before Ibn Arabi, others mentioned the unity of reality, but theorists are not in agreement about whether what existed before him had been the unity of being or unity of intuition, and although some people such as Khayyam (1121) and Ayn al-Quzat Hamadani who wrote epistles entitled unity of being, but if we see them, it appears that the level of discussions was not at the level of the unity of being as it should be. However, Muhyi al-Din Ibn Arabi, was the first one who used the term unity of being in the real meaning of the word (see: Ibn Arabi n. d.: 23). This issue which was merely considered as a mystic viewpoint and even sometimes posed as "Super-Rational" from the very beginning provoked some sensitivity and some people like Ala al-Dawlah Semnani, conceived it as pantheism and its followers were excommunicated. But followers of this school gradually started to describe and explain it, even some significant exegetes of this mystic school during the eighth and ninth century, such as Qaysari in the description and introduction of Fusus al-Hikam of Ibn Arabi and Sayyid Haydar Amoli in Jami' al-Asrar epistle and Manba' al-Anvar and particularly in its summarization, namely, in Naghd al-Noghoud epistole, Muhammad Hamzah Fanari in Misbah al-Uns, Abu Hamid Muhammad Ibn Isfahani in Qawa'id al-Tawhid and most importantly its exegete, Sa'in al-Din Ali Ibn Turke, who struggled in preparation of its rules in order to provide some reasons for a logical and philosophical demonstration of this theory; however, those reasons were also highly disputed (see: Ashtiani 1963, Ibn Tourke 1976). 
This description and interpretation never found any serious advocates and later, Mulla Sadra demonstrated that this view was based on the lack of differentiation between the intermediary's existence and the linking existence (see: Mulla Sadra 1981: 330). Moreover, his basis is more consistent with original nature and this basis is essentially inconsistent with pantheism (ibid.: 71-74).

By philosophically demonstrating existentialism, Mulla Sadra was able to open and pave the way for the main claim of gnosis, namely pantheism, and provide considerable demonstrations in this regard; but the issue of what kind of unity of being had been intended by him was disputed later on. All people accepted that Mulla Sadra had proved the analogical unity of existence, but whether this is the same unity of existence posed by Gnostics which was mainly mentioned as the personal unity of existence - or not, and in the least, what kind of relation and connection exist between the graded unity of being and personal unity of being, were gradually disputed; Gnostics particularly negated the multiplicity of existence (being) and believed in multiplicity of manifestations and thus even presented some reasons to reject the ambiguity (graded unity of being); but, very often in his works Sadra conceived the existence of the intermediary and manifestation to be identical and indeed in a way he believed that multiplicity of manifestations was retractable with the multiplicity of being (see: Mulla Sadra 1981: I/269, 291-294, 329; II/13, 14).

We know that after Mulla Sadra, his philosophy was taken into consideration for about one century until Agha Muhammad Bidabadi (1783) engaged in the revival of his philosophy. Not much of his works was available, but a very significant disciple of his, Mulla Ali Nouri (1830), who some people believed to be the first person in transcendentalism after Mulla Sadra (Ashtiani 1991: 172), in most of his remained works, by emphasizing the concept of mere-related possibilities like Mulla Sadra himself, interpreted the graded unity of being as the personal unity of being.

\section{Explanation of Reasoning}

There are realities in the external world.

These realities are not more than one unity and one thing.

This is the human mind that divides the external reality into two points of essence and existence (being).

Because of this, it becomes necessary that the external reality also be both unique and not unique. According to the previous premises, wisdom commands that one of these dimensions either essence or being, is real and exists objectively. After an intellectual analysis that, for example, human na- 
ture is a talking animal, it leads to a conclusion that in nature there is no place for being and realization. Now, what caused this nature to be realized and become real? The reason states that it has been given reality by being created by the creator - by the God. Now, the question is what has been forged? Essence, by itself, and even regarding its relation to the creator, cannot be as a fact, because it entails revolution in essence by itself which is impossible unless something is given to essence so that it could not be nothing. Hence, it is being that essence could be realized by endowment of being and existence. Now, how is it possible that the being would not be actual and real? Finally, by this intellectual analysis, it will be demonstrated that existence and realization is the being; in other words, being has an inherent realization and essence exists secondarily for the reality and existence of being.

\section{The Principle of Univocality of the Concept of Being}

Another important philosophical basis of Mulla Sadra's which can apply in the discussion of divine attributes is the principle of univocality, which means that the concept of being has been used in all its instances and implies the same meaning in all its instances.

In his treatise in Metaphysics, in the Arab world known as Kitab al-Huruf, which is regarded as the main origin of metaphysics, in article "A", Aristotle posed the issue of univocality of concept of existence and argued that the concept of existence is univocal.

Murtaza Mutahhari says that in the concerns of existence the issue of univocality of existence has been the only issue concerned since Aristotle's time; with this difference that in Aristotle's philosophy, this issue did not end into the unity of the being, while in the Islamic philosophy, it was established as the basis to demonstrate (prove) the unity of the being.

Among Islamic philosophers and scholastics, this issue has been specifically considered and has been precisely investigated in detail. Among them there is no disagreement on the issue that the concept of existence can refer to different existents because it is wholly believed that it can be stated that God exists, humans exist, plants exist, etc. However, there is a disagreement on whether attributing the existence to different beings has a single meaning or if it has a specific meaning for each existent? In other words, can the concept of existence for different existents be applied to the univocal or to the equivocality?

Another one of their disagreements is whether the concept of existence is merely a general concept which is purely sophisticated or a sophisticated concept based in reality and an abstracted one which has an origin of abstraction and actual instances. 
Many Islamic philosophers and scholastics are among the advocates of the issue of the univocality of the concept of existence and some of its believers such as Imam Fakhr al-Din al-Razi, Khwaja Nasir al-Din Tusi, Mulla Sadra, and Muhaqqiq Lahiji have even confirmed its evidence; and they have considered its evidence and seemed that there is no need to prove it except for reminding and getting attention.

Mulla Sadra believes that univocality of the concept of existence is almost an evident issue; occasionally, when arguments are presented to prove it, he believes that deniers of the univocality unconsciously believe in the demonstration of the univocality, because if the existents did not have any unity even in the concept of the being (as deniers believe), then there would remain no common magnitude along with nothingness; hence, one could not say whether this being has something in common with another being or not. Just as a mandate for commonness should exist in something, a mandate for uncommonness should also be in something; we argue that this thing is the same as a being, then, it was demonstrated that, in any case, the being is common among the existents (see: Mulla Sadra 1981: I/ 35-36).

\section{The Principle of Gradation of Being}

The third principle which is important in Mulla Sadra's philosophical system and is considered as one of the significant applied principles on which, many philosophical and even theological drawbacks can be resolved is the principle of gradation. In order to explain the being principle of gradation it can be stated that based on the basis of existentialism, in the external world, that there is no original thing having an effect unless the being has reality, and also, according to the multiplicity and differences existing among the entities should be referred to the being itself.

Therefore, since on the one hand, the concept of being refers to a meaning for various creatures, and of course, there are some differences among the creatures, inevitably, the difference also refers back to the "being" itself. Being has been analogized as the reality of light since it has multiplicity while having unity. The following statement clearly explains the gradational system of being:

"They are multiple because the general obvious concept of being is abstracted from their steps and instances and it is impossible to abstract a concept from the multiple instance which do not refer to unity." (Tabatabai 1991: 18)

The author of the Enneads used the same interpretation and wrote: 
"The mere unity which is the cause of all things, while it not included in them but rather they are covered this unity." (Plotinus 1984: 103)

Mulla Sadra Shirazi writes on this subject presented in Enneads ascribed to Aristotle:

"What is understood by the expression of The First Teacher that he has rejected in the places of his books of Theologia and this is supported by argument." (Mulla Sadra 1981: VII/33)

In Avicenna's works many instances can be found which confirm the obviousness of this concept more or less. For example:

"The Necessary Being is Complete Being [...] but the necessary being is upper than completeness because he is not as that existence relates to him only but he is being all by all the existence flew up from his horizon." (Ibn Sina 1997: 380, 391)

Also, Mulla Sadra's master, namely, Mir Damad explained the contents of this rule in the books Ghabasat and Taghdisat:

"He is all Existence and $\mathrm{He}$ is all Being and Glory and all glories and perfection are for Him and what else things are the appearances of His Light and Existence, shadow of his Essence. And because all entities come His Absolute Being and there in no absoluteness except Him." (Mulla Sadra 1981: VI/111)

Abul-Qasim Ferdousi (941-1020) in Shahnama and Attar (1146-1229) in Mantiq al-Tair, in some couplets praising the God, pointed to this rule.

So, it is not inappropriate to mention a point at the end of the history of this rule:

Just as priority in terms of time does not mean priority in terms of rank, if someone is prior in setting a question forth, does not mean his priority in knowledge.

\section{Explanation of Doctrine "Simple Exitsence"}

Mulla Sadra in his work repeatedly explains this doctrine, for example, he says: We have said before, that we have our specific manure that is divine and no one has known it before. According to this doctrine the Necessary Being is Simple but Perfect. This principle is explained as: 
1. All need to turn to the Necessary Being, but He is not in need to other than Himself, so He is All-Rich.

2. He who is All-Rich does not lack any perfection, therefore is not composed of having and lacking something; so $\mathrm{He}$ is simple.

3. Any kind of perfection is obligatory for Necessary Being otherwise it will not be All-rich.

Thus, all perfections are necessary for the Necessary Being and He is All-Rich but simultaneously Simple or it may be said that He enjoys all perfection without their material facets; that is to say "Simple Egsistence is all things but not one of them" (see: Mulla Sadra 1984: 205).

\section{Knowledge of God}

In this part of our paper, we discuss the knowledge of God and Mulla Sadra's view on this. He is of the view that man can have knowledge of God. So, he speaks of the relation between God and man. As men are different in their perception of God, we cannot say that God is indefinite and that there is indefinite border between God and man as we should hold the theory of negative language of the Quran, but, humans are a manifestation of God's attributes and represent various epiphanies of the Almighty God and each one of them is not at the same level. Consequently, the human achieves the knowledge of God according to his existential status, but the existential status (degree) and its domain is too narrow and learning it is very difficult; thoughts are unable to completely perceive it, but except a little part of it which is as a red match that no one other than masters of the other world can reach. Most of these enigmas and cues for thinkers and sages include their returning to the pure sanctification or pure transcendence (purification) and are merely negation of deficiencies; but there are plenty of attributes which can be used by them and many verses including its description such as science and power; however, this destination has also some difficulties and is far beyond the reach of incapable wisdoms. Attributes are like a wide sea with an infinite shore; also in the opinion of the Gnostics the divine Suq' has three degrees:

The first degree is the "Invisible of the Invisibles", a position that no one can achieve and it is the most hidden of them all, even the holy Prophet (peace be upon him) is deprived of perception of this degree; however, perceiving the Essence (Being) is impossible except for Him Essence. By manifestation of the essence, the oneness degree is manifested, where names and attributes totally appeared. There is a disagreement among mystics regard- 
ing whether it is possible for anyone to perceive the degree of oneness. The next degree (position) is the unity in which names and attributes elaborately appeared; therefore, what Mulla Sadra meant by possibility of knowing the essence was not the perception of the Secret of the secrets (invisible of the invisibles) (see: McDermott 1984: 55).

\section{Mulla Sadra's Viewpoint about the Word of God and its Dignities}

According to Mulla Sadra, although outward aspects of the Quran and also Hadith have other implications and interpretations, they are right and true. In order to prove this claim, Mulla Sadra resorted to both revealed causes and rational reasoning: revealed causes such as narratives indicating that the Quran has both outward and inward aspects; in other words, it has both external appearance and outer being and also limit and prologue. For example, in this luminous word of the Prophet Muhammad he says "Quran has apparent and hidden sides". And rational reasoning is that if the verses and hadith are not attributed to their original outward aspect and contents (of course without allegory and simile), and their appearances are not considered as proofs, their revelation to all people, which is emphasized by the Quran, would be useless and result in people's confusion and misdirection (see: Mulla Sadra 1981: II/431-432). Regarding their positions (degrees) in understanding the Quran's allegories, he divides people into three groups:

In the first group, there are those who take the homologous in the Quran in their respective meaning, sound of any mischief resulting in any kind of defect. In the second group there are intellectuals, the superficial Muslim scholars. These, due to their superficial views, do not go beyond rational arguments and interpret the homologous in accordance with their own presumptions. And in the third group there are Ahl al-Hadith, the corporeal view of God and literalists that have not gone beyond material world and endorse corporeal existence of God (see: Ebrahimi Dinani 1996).

Referring to "esoteric" and "exoteric" dimensions of the Quran according to Hadith, Mulla Sadra believed in both dimensions and again in a sequence of esoteric meanings that only God knows. He writes, the esoteric sequence of meanings of the Holy Quran resembles the esoteric sequence of man's existence, that is, Soul (Qalb), Reason, Spirit, Secret, Hidden and the most Hidden. The external detention of the Quran is what we notice, recite, perceive and learn by heart. Our inner sense does not catch the pure meaning but is mixed with corporeal accidents. Mulla Sadra names these two stages as external and earthly stages that man can perceive. But the two other stages, esoteric and secret are called heavenly and man cannot realize them as 
his soul does not go beyond the matter since sensible being is not eligible for rational thought just as reason is not eligible for sense through material means - sensible objects are bounded to situation, space, time, quality and quantity while the rational reality is included in these things. The human soul grasps sciences and knowledge through rational substance from empyrean world which is not located in material bodies and cannot come in sense and be imagined. As the senses act in the material world and the reason acts in the empyrean world, what is upper than material things and also than empyrean world, is hidden and secreted from both the senses and reason. Thus, the Quran says:

"Indeed, it is a noble the Quran; in a Register well-protected. Non touch it except the purified. [it is] a revelation from the Lord of the worlds." (56: 77-80)

Mulla Sadra's deduction from this verse is that, God stated numerous features according to the degrees and positions, best of which is dignity with God and the lowest one is devaluation (reduction) to humans (ibid.). He continues to say that the Quran has a higher degree which is best of all these degrees; none of the prophets except in the unity and abstraction from both worlds and attaining the "until he was within two bows' length or even nearer" position (degree) and passing from two worlds of creation and order, would not succeed in perceiving this position. To confirm his statement, he takes recourse to a hadith by the Prophet Muhammad where he says: "I have a time with God when even angels can't come in". The holder of this position (degree) specifically receives the Quran due to this degree. He believes that some verses also in hadith confirm this degree (Mulla Sadra 1984: 40), and that some other verses confirm the Heart and virtue of conscious (ibid.: 40-41). So, Mulla Sadra believes that as humans have positions and degrees, the Quran also has stages and degrees. The lowest degree of the Quran is what is seen in the sheath and this resembles the lowest human degree, i.e. what is seen in the skin and the body.

Each of the Quran's degrees has its own specific interpreter that except after outward and inward cleanness and purity and abandoning of his interests and the superficial human (who merely notices the outward aspect of the Quran) could perceive nothing but the superficial and outward meanings of the Quran; and no one can achieve the spirit and gist of the Quran other than those who possess intellect.

Mulla Sadra argues that the reality of wisdom can only be achieved through Divine-endowed science and once the soul achieves this rank, he will be a sage. Because the wisdom is granted and endowed by All-mighty God: 
"He gives wisdom to whom He wills, and whoever has been given wisdom has certainly been given much good. And none will remember except those of understanding." (Quran 2: 269)

Mulla Sadra thinks that those "who possess intellect" are those who have reached this step. There are some disputes and different theories about the implications of words just like there are disputes and differences amongst human-beings, because humans are at different levels. So, one can understand the meaning of the word? According to his level of humanity, in the way that according to what step he is located at, he will understand that step and the level of the word. Hence, the fact is that the comprehension of meanings of the Holy Quran and Divine Expression depends on the different level of humanity, in other words, the perception of Divine Expression depends in every world on the existential level of every human-being.

Among human beings, only the High Existence of Prophet Muhammad as the Perfect Man is able to take in all the realities of the Quran. So, symbolism of the Quranic language is not always absolute but rather relative.

\section{Receiving Revelation (Steps of Revelation)}

Mulla Sadra debates on the divine Sayings, its kinds and its difference with the Book before he discusses on how it comes down while we deal with the latter not the former one.

Mulla Sadra thinks about the coming down of Divine Speech that the origin of Divine Speech and it receiving through the human is to pay attention to God, and the purification of soul, keeping it away from material world and becoming close to another world.

He writes: As the human soul gets free from material things, gets rid of sins, sentimental, and normal wishes and relationships, the light of knowledge and belief will radiate on it. This light, when it gets intense, transforms in the Holy Substance which is called "Active Intellect" by philosophers and "Holy Spirit" in religious texts.

Through this intensive rational light, all secrets of earth and heaven and essences of things will appear before him, as he observes the imaging things with the visual sense, with the sight potency when there is no any obstacle or veil.

Mulla Sadra believes that the cover (curtain) that may exist in receiving the revelation is the effects of nature and its occupations; since based on the original nature, if no darkness such as atheism or a cover like a sin, occur in human's heart and soul, they will deserve to receive the light of wisdom and faith. Anyway, if the human's soul avoids the claims of nature and desires and 
involvement in lust and anger, and appeals to God and the world of pure intelligence, it will attach to the sublime happiness and the celestial mystery will be revealed to him and he will observe the wonders of the great divine signs; as God says:

\section{"He certainly saw of the greatest signs of his Lord." (Quran 53: 18)}

This soul with such a characteristic, when celestial and highly powerful, due to its linking to the superior, would dominate its underneath world and nothing would occupy it and in contrast to weak souls it can have command of both sides (see: Mulla Sadra 1981: VII/32).

As it is obvious, here, the graded unity of being principle constitutes the basis of Mulla Sadra's statements. Anyway, this celestial soul that has received the divine knowledge without human trainings and only through God, will notice, its powers reach its highest strength and it becomes an exemplified visage for human soul, so that he can see it by his celestial soul, and this visage is exemplified with sensations especially, ear and eye; because human ear and eye are the most honourable sensations. And therefore, he would see by his eyes that face as a concrete person of extreme beauty and would hear by his ears the most eloquent and beautiful rhythmic words. This person is like an angle that has been sent down by God's permission and carries the divine message and the words he hears.

This is a very divine Speech and he represents the tableaus which contain the divine book. In other words, the prophet first connects with the angel of revelation after passing the necessary steps with Holy Spirit and receives divine teachings while he sees divine signs with his rational vision and he listens to the divine voice with his ear. Then, the prophet comes down from this sublime position, sees the angel of revelation in a form of a sensible person, and observes with apparent listening and vision and listens to his speech.

After receiving revelation, he connects through his inner-side and spirit with the angel of revelation, receives the divine teachings from him, the glory signs of God and acquires the real rational speech from the angel who is the glory table. Then the angel represents for him in sensible face, listens to his voice in the form of organized sounds and words, and observes his action and the book in the written form and features which are sensible. Thus, all three, the angel, the voice and the book will end up in his senses and perceptions.

Mulla Sadra reminds us that the process of revelation it is not the task of an angel to transfer the revelation. In other words, the angel of revelation does not see any transforming and replacing, but its source is the prophet soul invoking and it fits transferring from the hidden world to the apparent 
world after the first journey from the apparent world towards the hidden world. In such a way the sensible faculties become under a situation thunder and the prophet becomes syncope, and then sees and listens and thus the revelation becomes actual. Mulla Sadra proscribes the viewpoint of Farabi about this issue and thinks that Farabi's theory is rooted in his ignorance about coming and covering down the revelation.

According to the foundations of Mulla Sadra's philosophy and inspiring from his sayings and expressions, we analyse: He thinks the religious language is cognitive and knowledge-giving. From his principles of thought, it can be grasped that he does not believe that the language of the religion among the viewpoints discussed in the domain of the language of the religion symbolic and His speech which has several degrees not mere metaphorical.

The argument for this viewpoint follows.

\section{The Symbolic Nature of Religious Language}

Mulla Sadra believes that being symbolic is a fact that has several layers and for those who cannot achieve the scope of all these layers of religion the unreachable parts of the religion would appear as allusive and sign language (Mulla Sadra 1984: 68). Mulla Sadra argues that the language of the Quran should be oriented to reality and it is due to this reason that he disagrees with the language of religion being metaphorical. He argues that if the language of the Quran was metaphorical it would lead to the disparagement of the apparent meanings of the Quran with reality since according to this theory, permissive parts and minutiae of the Quran and its words and propositions would directly seem real and would have no real implication. Mulla Sadra says that this is what we say about our understanding of the meanings of the Quran as it would not contradict the apparent mean of the Quran not such others who went in the excessive way to interpret such like they interpreted sitting on empyrean with mere imaging dignity and sublime, or Kursi with the knowledge and power and other instances as they interpreted them with mere imagination lack of to be graspable and acquirable because all of these are punishments that would not refer to those imaginations without any necessity and situational indication. It must be known that, no rule or regulation can be conceived for this notion and conjecture; then, how does it refer to them (see: ibid.: 250)? Thus, according to this thinker, this allusiveness of the Quran's language includes:

- Being Cognitive: the verses of the Quran including their inward and outward aspects have a dignity to grant wisdom and humans cannot know it. 
- All the meanings of religion will not be revealed in a direct language: what is understood from the outward aspect of the Quran, is not its entire fact and this outward aspect of the Quran is an allusion which refers to its real meanings that have been pointed to through illusions and its real and original meaning is hidden in its inward aspect.

\section{The Inherency of the Symbolic Nature of the Language of the Quran}

The language of the Quran is conventional but rather it is essential, and being essential is specified with Divine Speech. This character came down from the Empyrean world [Lahout and Jabarot] to the mundane and terrestrial world [Nasut]. So, saving all meanings of heaven (upper) world in lower [material] world is possible in the form of secret. All existential meanings of these worlds which came down from the heavenly world are hidden in the material world, essentially and full of secrets. Nay! It is a Quran is glorious in a guarded tablet $(85: 21,22)$. The Qaf is a secret of its own [Swear by Quran], because, even the Quran is one reality and essence, but it had different steps while (it was) coming down, and it took several names according to the steps of coming down. So, it is called by a specific name in every world appropriate to it.

\section{Refutation of Symbol Language}

There not being differences and controversy between the inner and apparent [outer] meaning of words is the most important condition of Mulla Sadra's in the Interpretation and Exegesis of the Holy Quran. According to this principle, we cannot take from metaphors and allegories where the word is meaningful even in similar verses. Because, the word is used in its non-real meaning in metaphorical language and it implies that there is variance between the apparent and concealed meaning of the word. Being symbolic of religious language is influenced by the theory of being actual and real of the Quranic Language. It means that mankind does not have any access to acquiring perception of the meaning of Divine Names and Attributes. And he has power to upgrade himself existentially to the level where he can get the real concepts of these meanings through self-knowledge, cognition of God, piety, purification of soul and offering worship. Vice versa of this theory, the meaning being symbolic of religious language is that, mankind is limited and the limited cannot perceive unlimited, so, the Quranic language has a cognitive reality. 


\section{Conclusion}

Mulla Sadra attempted to solve the issue of religious language which was an answer to the following question: How can a limited being grasp an unlimited one while using language as a tool that is something related to the limited domain? Is it possible to use words made for creatures for God with meaningfulness? Is not this incompatible with the being Transcendental of God? Therefore, he presented the theory of Gradation of Existence an the theory of Univocality of concept of existence.

According to this theory, religious propositions express sublime realities through the symbolic language, while they cannot be expressed except through language symbols and gestures. When we say "symbolic" it does not mean non-real but rather it is used in its real meaning, otherwise it would get out of the language of the Quran and religion from their realistic meaning and we become Ta'teel [do not know any meaning but just reciting].

So, first, religious language is meaningful in the viewpoint of Mulla Sadra.

Secondly, being meaningful is through symbol, secret and gesture.

Thirdly, symbolic is used in the real meaning.

Fourthly, being symbolic and conventional is rooted in the essence of religious language. The reason is that it came down from the heavenly world to the material world. So, it includes all of the Quran.

Fifthly, being secret is for those who live in the mundane world; those who have stepped forth and gained access to the heavenly world - they can receive the Quran directly.

Sixthly, there is no difference between the religious language and common language in concept, but the distinction is in their instance and object. So, the religious language is informative and one can also acquire discovering and intuiting the sublime and glory realities through it and even can know God.

Received: May 17 2016.

Accepted: August $3^{\text {rd }}, 2016$.

\section{References}

\section{Holy Quran.}

Ashtiani, Seyed Jalal al-Din (1963), Sharh al-Masha’ir, Tehran, Ilam School Publishing Centre.

Ashtiani, Seyed Jalal al-Din (1991), Sharh-e Moqaddameye Qeysari, Qom, Islamic Propagation Office. 
Barbour, Ian (1995), Science and Religion, translation: Bahaoddin Khorramshahi, $2^{\text {nd }}$ edition, Tehran, University Publications.

Ebrahimi Dinani, Gholam Reza (1996), The Right Names and Attributes, Tehran, Ahle Qalam.

Ibn Arabi, Muhyi al-Din Abu Muhammad ibn Ali (n. d.), Al-Futuhat al-Makkiyya, Beirut, Dar Sadir.

Ibn Sina (1997), Theology of Healing, ed.: allamah Hasan Hasanzadeh Amoli, Qom, Islamic Propagation Office of Qom Seminary.

Ibn Turke, Sa'in al-Din Ali ibn Muhammad (1976), At-Tamhid al-Qava'id, Introduction and correction: Seyyed Jalal al-Din Ashtiani, Tehran, Iranian Philosophy Society.

McDermott, Martin (1984), The Theology of al-Shaykh al-Mufid, translated by: Ahmad Aram, Tehran, Institute of Islamic Studies \& McGill University.

Mulla Sadra Shirazi (1981), Al-Hikmah al-Muta'aliya fi al-Asfar al-Aqliyya al-Arba'a, Beirut, Dar at-Turath.

Mulla Sadra Shirazi (1984), Mafatih al-Ghayb, Mohammad Khajavi, Tehran, Moula.

Plotinus, Enneads (1984), ed.: Abdul-Rahman Al-Badawi, School of Islamic Sciences Al-Alam.

Tabatabai, allama Muhamad Hossein (1991), Nihayat al-Hikmah, translation and commentary: Ali Shirvani, Qom, Daftare Tablighate Eslami. 